\title{
Job Satisfaction and Gender
}

\author{
Maureen Snow Andrade \\ Utah Valley University \\ Jonathan H. Westover \\ Utah Valley University \\ Jeff Peterson \\ Utah Valley University
}

Previous studies of job satisfaction and gender have had mixed results, with some finding that women enjoy greater satisfaction than men, and others no difference once other factors were accounted for. This study used data from the 2015 International Social Survey Programme to investigate if gender, country and work-based factors make a difference on employees' level of job satisfaction. Extrinsic rewards, intrinsic rewards, work relations and work-life balance rewards were examined. Overall there were no differences between women's and men's job satisfaction. In only one country was women's job satisfaction was significantly higher. Extrinsic outcomes were significantly lower for women.

Keywords: Job Satisfaction, Gender, Country, International, Extrinsic Rewards, Intrinsic Rewards, Work-based Factors

\section{INTRODUCTION}

Job satisfaction, defined as "a pleasurable or positive emotional state resulting from the appraisal of one's job or job experiences" (Locke, 1975, p. 1304) may be viewed globally in the sense of overall feelings about one's job, or on the basis of specific employment facets such as salary, growth opportunities, benefits, environment, or co-worker relationships (Mueller \& Kim, 2008). Knowledge about the latter can help organizations identify areas for improvement (Kerber \& Campbell, 1987) such as the need for job redesign to improve both satisfaction and performance (Grant, Fried, \& Juillerat, 2010). Although a number of fallacies surround job satisfaction such as happier workers are more productive workers (Bassett, 1994; Syptak, Marsland, \& Ulmer, 1999) and level of pay correlates to job satisfaction (Employee Retention Headquarters, n.d.), a rich literature on job satisfaction has identified extensive positive outcomes.

Benefits of job satisfaction for organizations include increased performance (Sousa-Poza \& Sousa Poza 2000) and productivity (Appelbaum \& Kamal, 2000), greater achievement (Lusch \& Serpkenci 1990), higher quality work (Tietjen \& Myers, 1998), increased competitiveness and success (Garrido, Perez, \& Anton, 2005), more customer satisfaction (Brown \& Lam 2008; Rogers, Clow, \& Kash, 1994; 
Ryan, Schmit, \& Johnson, 1996), improved organizational effectiveness (Koys, 2001; Ostroff, 1992), decreased employee turnover (Ryan et al. 1996), and less absenteeism (Vroom, 1964, 1995). Conversely, dissatisfied workers exhibit undesirable behaviors such as tardiness, absenteeism, and turnover (Bernstein \& Nash, 2008; Blau, 1994; Lee, 1998).

An additional issue in job satisfaction is what has been called the paradox of the satisfied female worker, based on findings that women's job satisfaction is higher than men's in spite of women earning lower salaries (Clark, 1997; Donohue \& Heywood, 2004). Further research in this area has identified inconsistencies in this paradox, however, indicating that gender differences in job satisfaction are a complex issue that merit further investigation. This research utilizes data from the International Social Survey Program (Work Orientations IV: 2015-survey questions on job characteristics and job quality) to examine the following:

1. Gender differences in job satisfaction levels across countries.

2. The role of extrinsic and intrinsic rewards in predicting job satisfaction levels for female and male workers across countries.

3. The effect of work relations on perceived job satisfaction levels for female and male workers across countries.

4. The impact of work-life balance rewards in predicting overall perceived job satisfaction levels for female and male workers across countries.

\section{LITERATURE REVIEW}

A substantial amount of research indicates that job satisfaction is higher for women than men across countries (Clark, 1997; Donohue \& Heywood, 2004; Kristensen \& Johansson, 2008; Loscocco \& Bose, 1998; Metle, 2001; Mulinge \& Mueller, 1998; Sloane \& Williams, 2000) and occupations (Bashaw, 1999; Dhawan, 2000; Grissom, Nicholson-Crotty, \& Keiser, 2012; Hull, 1999; McDuff, 2001) in spite of the fact they earn less. However, other studies have found no differences in job satisfaction between men and women, particularly when controlling for specific job variables (Bokemeier \& William, 1987; Ehrenberg, 2003; Fields \& Blum, 1997; Hodson, 1989; Mobley, Jaret, Marsh, \& Lim,1994; Robst et al., 2003; Westover, 2009; Zoghi, 2003). This review examines four key areas of job satisfaction and gender: extrinsic rewards, intrinsic rewards, work relations, and work-life balance.

\section{Extrinsic Rewards}

One explanation for gender job satisfaction differences is that men place more emphasis than women on extrinsic work benefits such as pay (Konrad et al., 2000; Sloane \& Williams, 2000; Donohue \& Heywood, 2004). Consequently, they may stay in jobs they find less satisfying (Dyke \& Murphy, 2006), and thus experience lower levels of satisfaction overall (Magee, 2015). This may differ by context and profession, however. For female university professors in the UK, the extrinsic factor of pay satisfaction was higher for women than men, but women experienced declining satisfaction with both teaching and research with increasing age and tenure, similar to men (Oshagbemi \& Hickson, 2003).

Another explanation for findings that women have higher job satisfaction than men is that married women may have more flexibility in job choice than do men and also than unmarried women, allowing them to leave unsatisfactory employment (Carleton \& Clain, 2012). Thus, when viewed collectively, women been shown to have higher job satisfaction than men; however, this is not the case when marital status is considered. One large-scale study found that married women had higher levels of job satisfaction than both married men and unmarried women while the latter two groups were comparable (Carleton \& Clain, 2012), thus demonstrating that being the primary income provider plays a role.

Promotion, another extrinsic variable, impacts job satisfaction and also varies by gender, possibly due to men being promoted to senior level jobs earlier and more readily than women (Clark et al., 1996; $\mathrm{Ng} \&$ Feldman, 2010). In these cases, the U-curve pattern, which indicates that employees experience moderately high job satisfaction in the early in years of employment, followed by a decline, and then a 
gradual increase up until retirement, has been shown to be stronger for men than women (Clark et al., 1996).

\section{Intrinsic Rewards}

Other explanations have also been made for the gender gap in job satisfaction, specifically that women feel more satisfied due to their overall improved conditions in the job market (Clark, 1997) (although this explanation may be dated), or that they seek the job characteristics they find the most fulfilling (Bender, Donohue, \& Heywood, 2005). The latter may be an option for married women, in particular, especially if they are not the main financial provider for a family. A number of studies have found that valued job features differ by gender (Bokemeier \& William, 1987; Hodson, 2002; Clark, 1997; Konrad, Corrigall, Lieb, \& Ritchie, 2000; Donohue \& Heywood, 2004; Westover, 2009).

One intrinsic characteristic accounting for gender differences in job satisfaction is job pride. Women under the age of 30 report more job satisfaction than men whereas from middle age to retirement, they report less satisfaction, but more pride (Magee, 2015). Women may feel satisfaction in their work in entry level positions as they expect to be in these types of positions at the beginning of their careers (Magee, 2015). Because they tend to stay in entry-level positions longer than men, this constrains their feelings of job pride at younger ages (Yap \& Konrad, 2009). When they are promoted in middle age, their pride increases (Magee, 2015). In contrast, job satisfaction (consisting of both intrinsic and extrinsic aspects of a job) has been shown to increase with age for both genders (Wilks \& Neto, 2012).

\section{Work Relations}

Another job feature that may impact gender differences in job satisfaction is work relations. Aspects of work other than pay may be more important to women than to men; these include social relations (Clark, 1997, Harris, Moritzen, Robitschek, Imhoff, \& Lynch 2001; Konrad et al., 2000), having a good supervisor, and task significance (Konrad et al., 2000). Female university professors in the U.S. and Canada experienced more job satisfaction than men when their work focused on teaching (which could be considered relationship-based) rather than research whereas for men this was the opposite (Kessler, Spector, \& Gavin, 2013).

Women may also experience more rewarding work relations in female-dominated employment environments. Women tend to be more satisfied in women-dominated work contexts (Fricke \& Beehr, 1992; Smart \& Ethington, 1987) and rate their organizations higher under these conditions (Clerkin, 2017) whereas they are less satisfied in male-dominated workplaces, perhaps because they have higher expectations in these environments (Clark, 1997; Sloane \& Williams, 2000).

Similarly, other factors such as unfair treatment and gender bias can also impact levels of satisfaction. A study in China found that women were less satisfied with their jobs than men, except in conditions of perceived organizational support, and that perceptions of gender bias had negative effects on career satisfaction (Ngo, Foley, Ji, \& Loi, 2014). For other work relations factors, such as job well-being (how a person feels while working), no gender differences have been observed. For both men and women, wellbeing has been shown to decrease with age (Wilks \& Neto, 2012).

\section{Work-Life Balance}

Another explanation for gender differences in job satisfaction may be accounted for by work-life balance variables. Women may place higher value on the ability to balance home and family whereas men may value pay over flexibility; when flexibility is accounted for, satisfaction is equal for men and women (Bender et al., 2005). Similarly, no gender gap is present in life satisfaction when mismatches occur between employees' actual and preferred number of work hours (Başlevent \& Kirmanoğlu, 2014). Although life satisfaction is not synonymous with job satisfaction, the two tend to correlate (Tait, Padgett, $\&$ Baldwin, 1989). A meta-analysis found that older women had more satisfaction with their supervisors and experienced less role overload (fulfilling multiple rules requiring extended time commitments) than their male counterparts (Ng \& Feldman, 2010). 
This review indicates that the generally accepted paradox that women experience more job satisfaction than men in spite of lower pay levels is inconsistent when a range of variables and work environments are accounted for, particularly when extrinsic, intrinsic, work relations and work-life variables are examined. Inconsistencies in findings and the potential of expanded insights from investigations of new contexts suggests the need for further study of gender differences in job satisfaction, however.

\section{Theoretical Framework and Model}

We have developed a theoretical model that synthesizes the literature to date on the core the drivers of job satisfaction and in explaining the influences on the experiences of workers and their overall job satisfaction. While many studies have pointed to the importance of various intrinsic, extrinsic, and work relations variables, this model also includes important contextual factors such as control variables for organizational and job characteristics. Additionally, and most germane to this current research, we include a gender variable in the individual controls.

\section{FIGURE 1}

\section{FACTIONS INFLUENCING WORK CHARACTERISTICS AND JOB SATISFACTION}

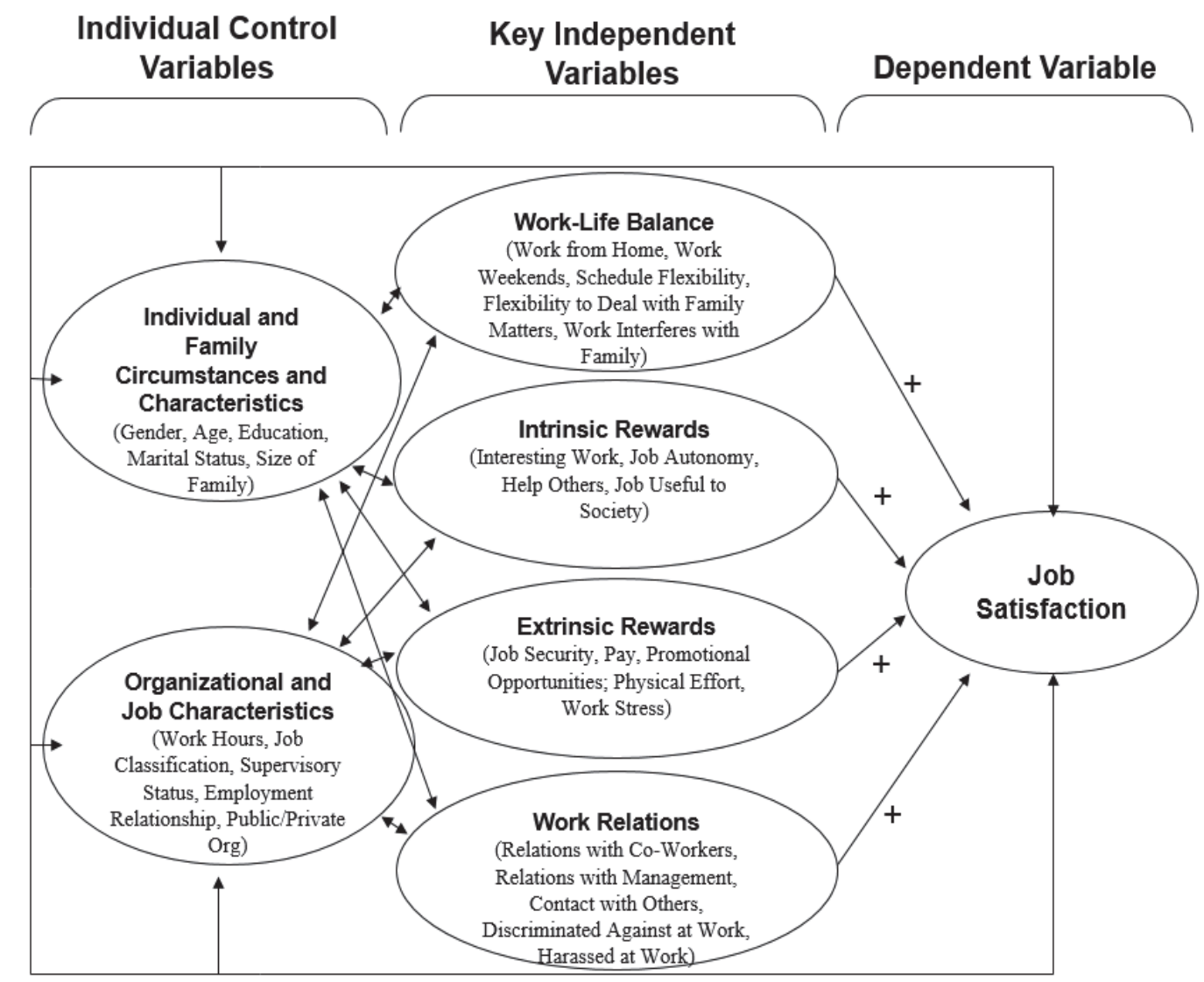

\section{RESEARCH DESIGN AND METHODOLOGY}

As was previously noted, many empirical studies have found that women tend to enjoy significantly higher levels of job satisfaction than their male counterparts (Roxburgh, 1999; Clark, 1997; Sousa-Pouza and Sousa-Pouza, 2000; Bender et al., 2005), while other studies have found no such differences, 
particularly after controlling for other relevant workplace and organizational factors (Brush et al., 1987; Hodson, 1989; Bokemeier and William, 1987;

Mobley et al., 1994; Fields and Blum, 1997; Westover, 2009, 2010a). Despite this ongoing debate, continued research efforts in the area of gender and work have shown that the job characteristics valued by women and men tend to differ, with women being less likely than men to be motivated by extrinsic work rewards such as pay and responsibility and more likely to be motivated by intrinsic rewards and the quality of workplace relations (Bokemeier andWilliam, 1987; Hodson, 1989; Clark, 1997;Konrad et al., 2000; Donohue and Heywood, 2004; Westover, 2008b, 2010a).

\section{Hypotheses}

Based on what is suggested in the literature, the hypotheses for this study are as follows:

\section{Job Satisfaction by Gender}

H1: When controlling for other work characteristic and individual factors, there will not be consistent statistically significant gender differences in job satisfaction levels across countries.

\section{Job Satisfaction Determinants by Gender}

H2a: Extrinsic rewards will be more salient and provide a greater level of predictability in overall perceived job satisfaction levels for male workers than their female counterparts.

H2b: Intrinsic rewards will be more salient and provide a greater level of predictability in overall perceived job satisfaction levels for female workers than their male counterparts.

H2c: Work relations will be more salient and provide a greater level of predictability in overall perceived job satisfaction levels for female workers than their male counterparts.

H2d: Work-life Balance rewards will be more salient and provide a greater level of predictability in overall perceived job satisfaction levels for female workers than their male counterparts.

\section{Description of the Data}

Following the approach of Westover (2012a; 2012b), we use non-panel longitudinal data from the 2015 wave of the International Social Survey Program (ISSP) Work Orientations Modules IV — various survey questions on job characteristics and job quality ${ }^{1}$. The International Social Survey Program Work Orientations modules utilized a multistage stratified probability sample to collect the data for each of the various countries with a variety of eligible participants in each country's target population ${ }^{2}$. As Westover noted, "The International Social Survey Program Work Orientations modules utilized a multistage stratified probability sample to collect the data for each of the various countries with a variety of eligible participants in each country's target population" (2012a, 3). 37 countries participated in the 2015 wave $^{3}$. Additionally, following the approach of Westover:

The Work Orientations module focuses on the areas of general attitudes toward work and leisure, work organization, and work content. Variables of interest in the data collected by the International Social Survey Program are single-item indicators (i.e. with a single survey question for job satisfaction, interesting work, job autonomy, workplace relations, etc., on a Likert scale). For the purposes of this study, the units of analysis start with individuals within the separate sovereign nations. In addition to examining one large sample including all respondents from all participating countries, we examine a separate sample for each age cohort to determine which job characteristics best predict job satisfaction among that particular age cohort and then make comparisons (2012a, 3). 


\section{Operationalization of Variables}

We use Handel's (2005) job satisfaction model (based on Kalleberg's 1977 findings) for conducting a cross-national comparison of job satisfaction and the perceived importance of intrinsic and extrinsic job quality characteristic and work relations across countries (see also Spector 1997; Souza-Poza \& SouzaPoza 2000; de Bustillo Llorente \& Macias 2005). Following the approach of Handel (2005), 10 intrinsic and extrinsic variables were available for all countries in the 2015 Work Orientations data and thus utilized for this study. Additionally, as can be seen in Table 2 below $^{4}$, we included important variables related to the meaning individuals give to their work, workplace discrimination/harassment, and work-life balance and schedule flexibility (in addition to a range of individual control variables).

\section{TABLE 1}

\section{KEY CHARACTERISTICS RELATED TO JOB SATISFACTION}

\begin{tabular}{|c|c|}
\hline \multicolumn{2}{|l|}{ Dependent Variable: } \\
\hline Job Satisfaction ${ }^{5}$ & "How satisfied are you in your main job?" \\
\hline \multicolumn{2}{|l|}{ Intrinsic Rewards ${ }^{6}:$} \\
\hline Intrinsic Rewards & "My job is interesting." \\
\hline Job Autonomy & "I can work independently." \\
\hline Help Others & "In my job I can help other people." \\
\hline Help Others & My job is useful to society." \\
\hline \multicolumn{2}{|l|}{ Extrinsic Rewards ${ }^{7}$ : } \\
\hline Pay & "My income is high." \\
\hline Job Security & "My job is secure." \\
\hline Promotional Opportunities & "My opportunities for advancement are high." \\
\hline Physical Effort ${ }^{8}$ & "How often do you have to do hard physical work?" \\
\hline Work Stress $^{9}$ & "How often do you find your work stressful?" \\
\hline \multicolumn{2}{|l|}{ Work Relations: } \\
\hline $\begin{array}{l}\text { Management-Employee } \\
\text { Relations }{ }^{10}\end{array}$ & $\begin{array}{l}\text { "In general, how would you describe relations at } \\
\text { your workplace between management and } \\
\text { employees?" }\end{array}$ \\
\hline Coworker Relations $^{11}$ & $\begin{array}{l}\text { "In general, how would you describe relations at } \\
\text { your workplace between workmates/colleagues?" }\end{array}$ \\
\hline Contact with Others ${ }^{12}$ & "In my job, I have personal contact with others." \\
\hline Discriminated against at Work ${ }^{13}$ & $\begin{array}{l}\text { Over the past } 5 \text { years, have you been discriminated } \\
\text { against with regard to work, for instance, when } \\
\text { applying for a job, or when being considered for a } \\
\text { pay increase or promotion?" }\end{array}$ \\
\hline Harassed at Work $^{14}$ & $\begin{array}{l}\text { "Over the past } 5 \text { years, have you been harassed by } \\
\text { your supervisors or coworkers at your job, for } \\
\text { example, have you experienced any bullying, } \\
\text { physical, or psychological abuse?" }\end{array}$ \\
\hline \multicolumn{2}{|l|}{ Work-Life Balance } \\
\hline Work from Home ${ }^{15}$ & $\begin{array}{l}\text { "How often do you work at home during your } \\
\text { normal work hours? }\end{array}$ \\
\hline Work Weekends $^{16}$ & $\begin{array}{l}\text { "How often does your job involve working } \\
\text { weekends? }\end{array}$ \\
\hline Schedule Flexibility ${ }^{17}$ & "Which of the following best describes how your \\
\hline
\end{tabular}


working hours are decided (times you start and finish your work)?

\section{Flexibility to Deal with Family Matters $^{18}$}

Work Interferes with Family ${ }^{19}$
"How difficult would it be for you to take an hour or two off during work hours, to take care of personal or family matters?

"How often do you feel that the demands of your job interfere with your family?"

\section{Individual and Family Circumstances and Characteristics}

As indicated by Westover (2012b, 17) "the literature has identified many important individual control variables, due to limitations in data availability, control variables used for the quantitative piece of this study will be limited to the following individual characteristics: (1) $\mathrm{Sex}^{20}$, (2) $\mathrm{Age}^{21}$, (3) Years of Education $^{22}$, (4) Marital Status ${ }^{23}$, and (5) Size of Family ${ }^{24}$ (see Hammermesh 1999; Souza-Poza and \& Souza-Poza 2000; Hodson, 2002; Carlson and Mellor 2004)" (2012b, 17) Additionally, an age cohort variable was coded based on the respondents' birth year: (1) Silent Generation: 1918-1942, (2) Baby Boomer: 1943-1963, (3) Generation X: 1964-1981, and Millennials: 1982-2000.

\section{Organizational and Job Characteristics}

While there are many possible control variables that would be helpful in this analysis, availability of all such variables is not consistent across all countries in the 2015 ISSP Work Orientations data. As such, organizational and job characteristics control variables used in this analysis were limited to the following: (1) Work Hours ${ }^{25}$, (2) ISCO Job Classification ${ }^{26}$, (3) Supervisory Status ${ }^{27}$, (4) Employment Relationship $^{28}$, and (5) Public/Private Organization ${ }^{29}$ (see Hammermesh, 1999; Souza-Poza \& SouzaPoza, 2000).

\section{Statistical Methodology}

We analyzed work orientation and job satisfaction data from individual respondents in the 37 countries included in the 2015 Work Orientations wave of the International Social Survey Program. First we performed a range of bivariate and multivariate analyses (e.g. correlations, cross-tabulations, trend analysis, ANOVA and ANCOVA procedures, and general descriptive statistics) on the work characteristics and attitudes in each country, which provides a basis for making descriptive comparisons between countries. Additionally, we ran aggregate and country-specific OLS regression models to examine the differences between countries in the impact of individual work characteristics on job satisfaction. It is worth noting that some studies examining worker satisfaction have used Ordinary Least Squares Regression (OLS) (see Handel, 2005), others have pointed to ordered probit regression (used when the dependent variable is ordered and categorical). I ran identical models using both OLS and ordered probit procedures (see Souza-Poza and Souza-Poza, 2000) ${ }^{30}$. Upon comparing the OLS and ordered probit results, I have come to the same conclusion that for the purposes of comparing coefficients and significance across countries and across models, as well as for overall ease of interpretation of the results, OLS is sufficient (however, full ordered probit results are all available upon request).

\section{RESULTS}

\section{Descriptive Results}

Figure 2 below shows mean job satisfaction levels across the 37 countries included in the 2015 wave of ISSP Work Orientations data. Of note is the general variation across countries and regions of the world. The highest job satisfaction levels are in Venezuela, Switzerland, Austria, and Mexico (means between 5.7-5.9), while most countries have a mean job satisfaction scores in the 5.2-5.4 range (overall world-wide mean is 5.3). Poland, China, and Japan have the lowest mean job satisfaction scores (means between 4.5-4.8). 
Additionally, Table 2 shows the comparative means of main study variables, by gender shows little difference in mean job satisfaction scores between men and woman (slightly in favor of men), with little difference in each of the intrinsic job characteristics (descriptive results by country are available upon request). However, there were significant differences in pay, promotional opportunities, physical effort (significantly lower mean scores for women), work weekends, and flexibility to deal with family members (significantly higher mean scores for women), as well as in education level (women in the sample were significantly more education, on average, than men) and work hours (men worked consistently more hours, on average, than their female counterparts). These results are consistent with prior research examining gender differences in job satisfaction and job characteristics (Brush et al., 1987; Bokemeier and William, 1987; Hodson, 1989; Blau and Kahn, 1992; Lynch, 1992; Mobley et al., 1994; Roxburgh, 1999; Clark, 1997; Konrad et al., 2000; Donohue and Heywood, 2004; Westover, 2008; Westover, 2012).

FIGURE 2

MEAN JOB SATISFACTION, BY COUNTRY

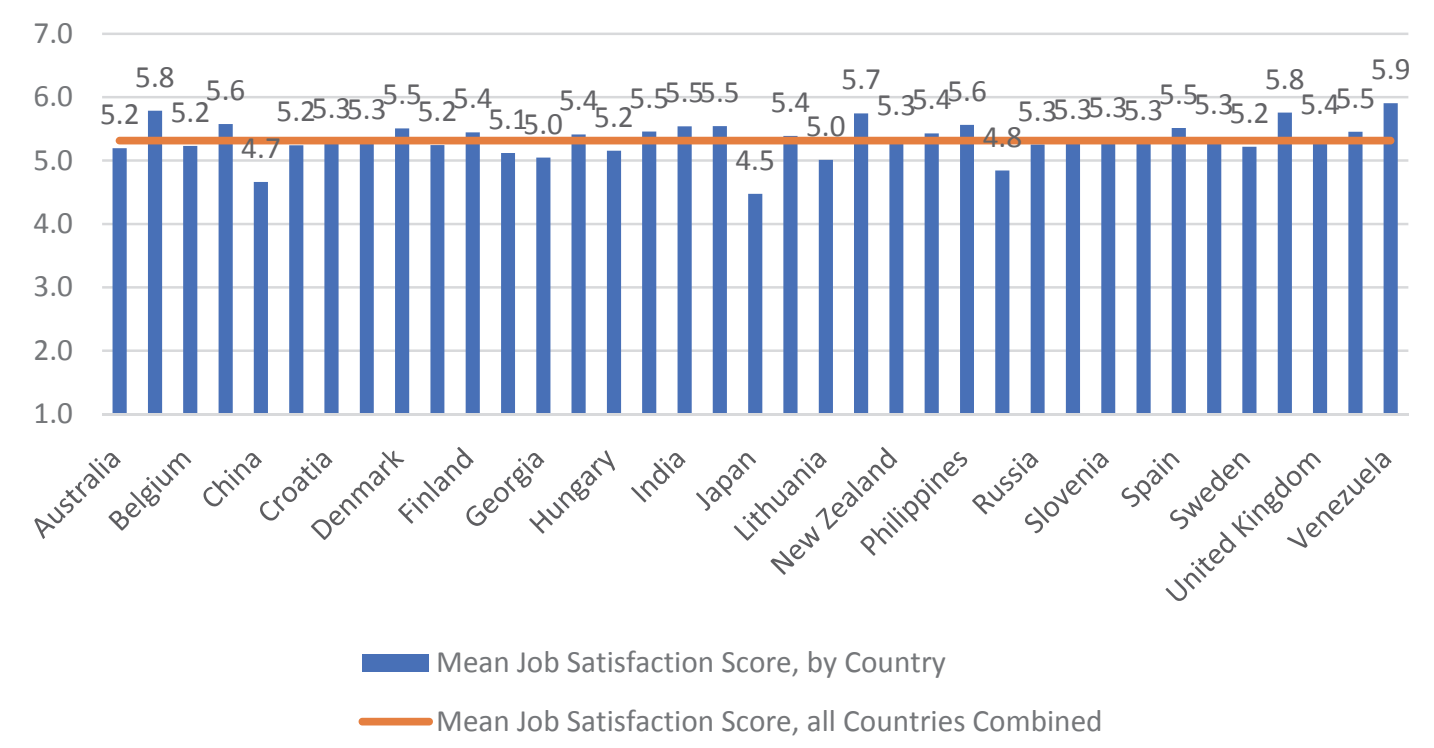


TABLE 2

MEAN SCORES OF JOB SATISFACTION AND MAIN STUDY VARIABLES BY GENDER, 2015

\begin{tabular}{|c|c|c|c|}
\hline VARIABLE & $\frac{0}{\Sigma}$ & 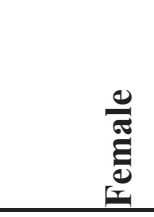 & 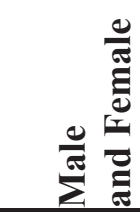 \\
\hline Job Satisfaction & 5.34 & 5.29 & 5.32 \\
\hline Interesting Work & 3.83 & 3.83 & 3.83 \\
\hline Job Autonomy & 3.85 & 3.78 & 3.82 \\
\hline Help Others & 3.81 & 3.96 & 3.88 \\
\hline Job Useful to Society & 3.89 & 4.00 & 3.94 \\
\hline Job Security & 3.76 & 3.79 & 3.77 \\
\hline Pay & 2.96 & 2.68 & 2.82 \\
\hline Promotional Opportunities & 2.87 & 2.68 & 2.78 \\
\hline Physical Effort & 2.92 & 2.49 & 2.71 \\
\hline Work Stress & 3.17 & 3.17 & 3.17 \\
\hline Relations with Coworkers & 4.19 & 4.18 & 4.19 \\
\hline Relations with Management & 3.92 & 3.90 & 3.91 \\
\hline Contact with Others & 4.17 & 4.29 & 4.23 \\
\hline Discriminated Against at Work & 1.82 & 1.81 & 1.82 \\
\hline Harassed at Work & 1.88 & 1.84 & 1.86 \\
\hline Work from Home & 3.96 & 4.04 & 4.00 \\
\hline Work Weekends & 3.03 & 3.25 & 3.14 \\
\hline Schedule Flexibility & 1.68 & 1.57 & 1.63 \\
\hline $\begin{array}{l}\text { Flexibility to Deal with Family } \\
\text { Matters }\end{array}$ & 2.15 & 2.35 & 2.25 \\
\hline Work Interferes with Family & 3.63 & 3.68 & 3.66 \\
\hline Age & 43.51 & 43.23 & 43.37 \\
\hline Education & 13.00 & 13.69 & 13.34 \\
\hline Size of Family & 3.30 & 3.16 & 3.23 \\
\hline Work Hours & 44.01 & 37.81 & 40.96 \\
\hline
\end{tabular}

\section{Regression Models}

To fully examine the association between job satisfaction and the independent variables (including gender), six regression analyses were conducted on the aggregated data for all countries in the 2015 wave of Work Orientations data (see Table 3 below). The first base model, which regresses job satisfaction on the individual control variables, examines how much variance in job satisfaction is accounted for by the control variables. The next four analyses (models 1 through 4) pertain to the separate analysis of the intrinsic, extrinsic, work relations, and work-life balance independent variables, and involve regressing each of these factors on job satisfaction. The last analysis (combined model) jointly examines the influences of all the independent variables (intrinsic, extrinsic, work relations, and work-life balance) and the control variables on job satisfaction. 


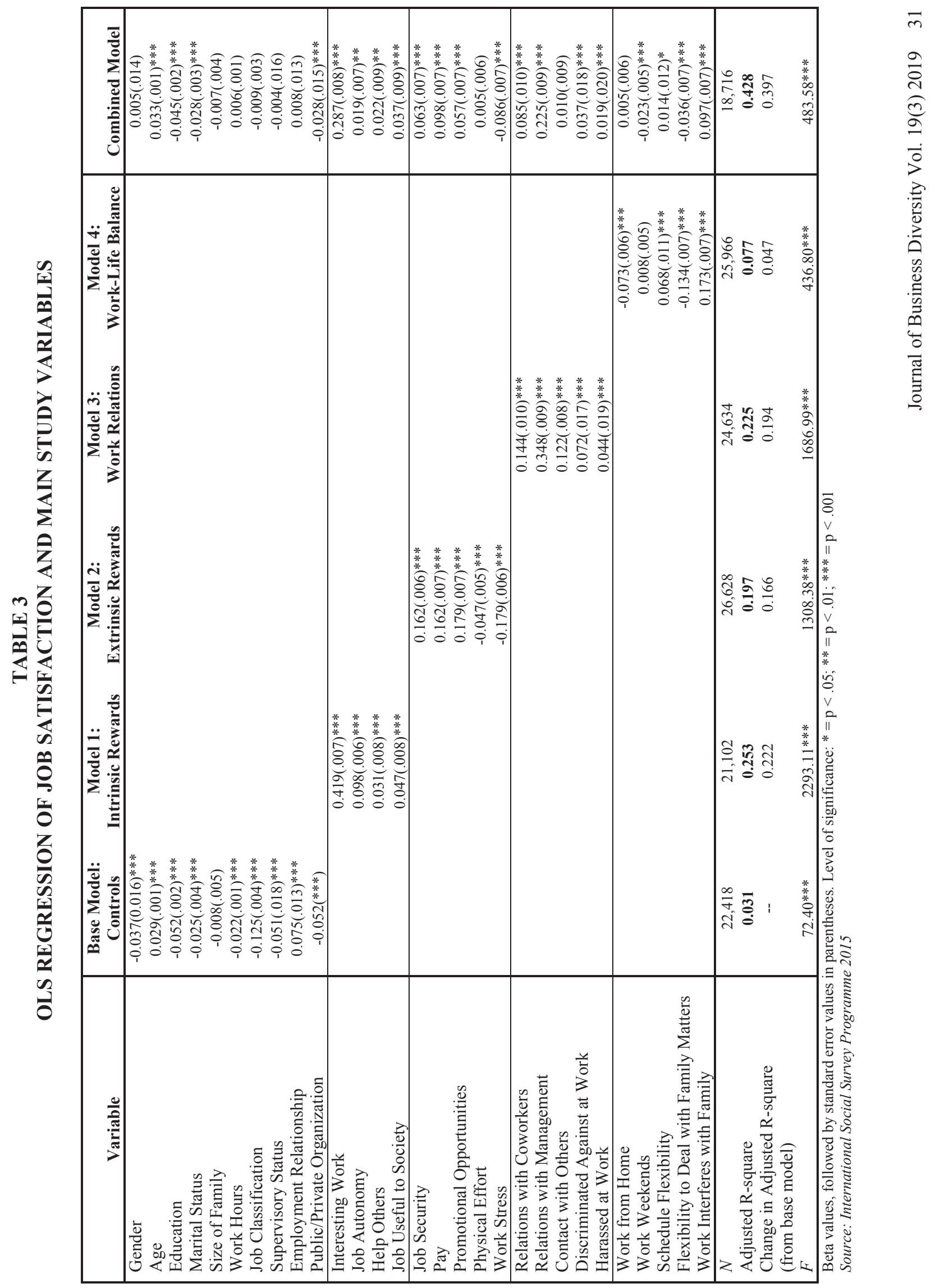


Nearly all variables were statistically significant $(\mathrm{p}<.001)$ when the individual base model and models 1-4 were run, with the exception of size of family as a control variable and working weekends as a work-life balance variable. However, when all of the individual models were included in the combined model, working weekends was significant, while physical effort, contact with others, working from home, and several individual control variables fell out of significant in the combined model. While the base model with just control variables only predicted 3\% of the variation in job satisfaction (adjusted r-square $=0.031$ ), intrinsic rewards variables accounted for $25 \%$ of the variation in job satisfaction (adjusted $\mathrm{r}$ square $=0.253$ ), extrinsic rewards variables accounted for nearly $20 \%$ of the variation in job satisfaction (adjusted r-square $=0.197$ ), work relations variables accounted for nearly $23 \%$ of the variation in job satisfaction (adjusted r-square $=0.225$ ), and work-life balance variables accounted for nearly $8 \%$ of the variation in job satisfaction (adjusted $r$-square $=0.077$ ). The combined model with all intrinsic, extrinsic, work relations, work-life balance, and control variables accounted for nearly $43 \%$ of the variation in job satisfaction (adjusted r-squared $=0.428$ ).

Finally, the above specified combined model was then run for each individual country included in the 2015 wave of Work Orientations data (full regression results by country are available upon request). As can be seen in Figure 3 (and full regression results by gender in Table 4), there is a great deal of variation between countries in standardized beta coefficient statistical significance for each of the intrinsic, extrinsic, work relations, and work-life balance job characteristics and control variables in predicting job satisfaction, including gender.

FIGURE 3

\section{MODEL FIT: JOB SATISFACTION MODEL ADJUSTED R-SQUARED, BY COUNTRY}

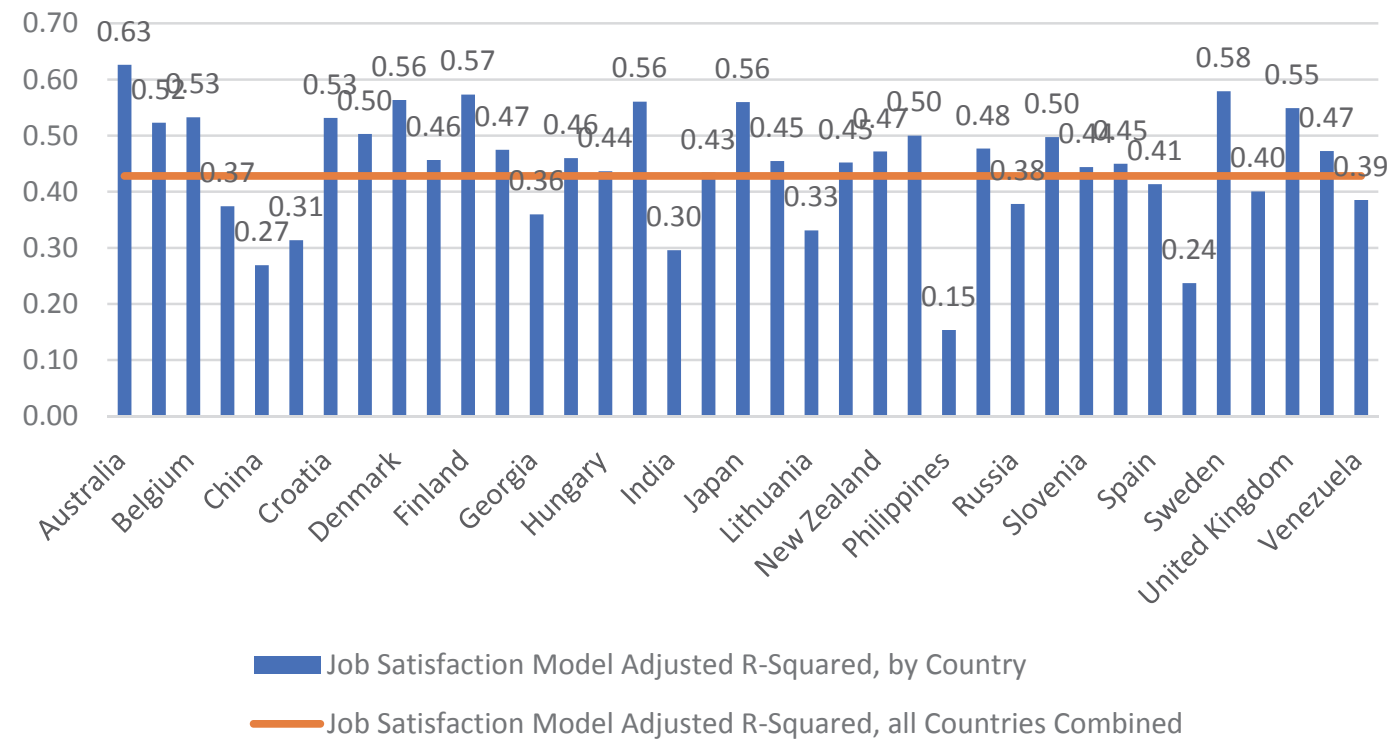

Additionally, when examining gender variations in specific standardized beta coefficient statistical significance for each of the intrinsic, extrinsic, work relations, and work-life balance job characteristics and control variables in predicting job satisfaction, certain patterns begin to emerge (see Table 4). While extrinsic and control variables were consistent in significance and direction for both men and women, there was variation in the intrinsic, work relations, and work-life balance job characteristics. More specifically, "Helping Others" is significant for women, not men, while "Contact with Others," "Harassed at work," "Working Weekends," and "Scheduling Flexibility" is significant for men, not women.

Of specific interest and focus of this particular study is the impact of gender on job satisfaction. Gender was not a statistically significant control variable in the overall model including respondents from 
all countries, and when country-specific models are run, gender is only statistically significant 1 of the 37 countries; Georgia (full regression results by country are available upon request).

\section{TABLE 4 \\ REGRESSION RESULTS OF JOB SATISFACTION AND MAIN STUDY VARIABLES, BY GENDER}

\begin{tabular}{|c|c|c|c|}
\hline VARIABLE & $\frac{0}{\frac{0}{J}}$ & 苋 & 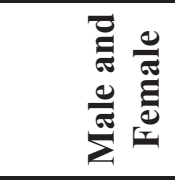 \\
\hline Interesting Work & $0.279 * * *$ & $0.295 * * *$ & $0.287 * * *$ \\
\hline Job Autonomy & $0.018^{*}$ & $0.020 *$ & $0.019 * *$ \\
\hline Help Others & 0.0170 & $0.028 * *$ & $0.022 * *$ \\
\hline Job Useful to Society & $0.042 * * *$ & $0.031 * *$ & $0.037 * * *$ \\
\hline Job Security & $0.061 * * *$ & $0.064 * * *$ & $0.063 * * *$ \\
\hline Pay & $0.092 * * *$ & $0.103 * * *$ & $0.098 * * *$ \\
\hline Promotional Opportunities & $0.060 * * *$ & $0.055 * * *$ & $0.057 * * *$ \\
\hline Physical Effort & 0.0086 & 0.002 & 0.005 \\
\hline Work Stress & $-0.080 * * *$ & $-0.093 * * *$ & $-0.086^{* * *}$ \\
\hline Relations with Coworkers & $0.075 * * *$ & $0.094 * * *$ & $0.085 * * *$ \\
\hline Relations with Management & $0.226 * * *$ & $0.224 * * *$ & $0.225^{* * *}$ \\
\hline Contact with Others & $0.019 *$ & 0.000 & 0.010 \\
\hline Discriminated Against at Work & $0.040 * * *$ & $0.034 * * *$ & $0.037 * * *$ \\
\hline Harassed at Work & $0.026 * *$ & 0.011 & $0.019 * * *$ \\
\hline Work from Home & 0.0045 & 0.007 & 0.005 \\
\hline Work Weekends & $-0.033 * * *$ & -0.015 & $-0.023 * * *$ \\
\hline Schedule Flexibility & $0.019 *$ & 0.006 & $0.014 *$ \\
\hline $\begin{array}{l}\text { Flexibility to Deal with Family } \\
\text { Matters }\end{array}$ & $-0.044 * * *$ & $-0.027 * * *$ & $-0.036 * * *$ \\
\hline Work Interferes with Family & $0.086 * * *$ & $0.109 * * *$ & $0.097 * * *$ \\
\hline Age & $0.029 * * *$ & $0.040 * * *$ & $0.033 * * *$ \\
\hline Education & $-0.051 * * *$ & $-0.037 * * *$ & $-0.045 * * *$ \\
\hline Marital Status & $-0.022 *$ & $-0.034 * * *$ & $-0.028 * * *$ \\
\hline Size of Family & -0.0117 & 0.001 & -0.007 \\
\hline Work Hours & 0.0008 & 0.011 & 0.006 \\
\hline Job Classification & -0.0110 & -0.006 & -0.009 \\
\hline Supervisory Status & -0.0040 & -0.005 & -0.004 \\
\hline Employment Relationship & 0.0051 & 0.008 & 0.008 \\
\hline Public/Private Organization & $-0.021 *$ & $-0.037 * * *$ & $-.028 * * *$ \\
\hline$N$ & 9,481 & 9,235 & 18,716 \\
\hline ADJ. R-SQUARED & 0.420 & 0.436 & 0.428 \\
\hline$F$ & $245.79 * * *$ & $256.25 * * *$ & $483.58 * * *$ \\
\hline
\end{tabular}

Beta Values; Level of significance: $*=\mathrm{p}<.05 ; * *=\mathrm{p}<.01 ; * * *=\mathrm{p}<.001$ 


\section{Revisiting Hypotheses and Future Research}

While many empirical studies have found that women tend to enjoy significantly higher levels of job satisfaction than men (Roxburgh, 1999; Clark, 1997; Sousa-Pouza and Sousa-Pouza, 2000; Bender et al., 2005), not all findings have been completely conclusive, and many studies have either found inconsistent or no significant gender gap in job satisfaction and its determinants, particularly when controlling for other workplace and personal characteristics (Bokemeier and William, 1987; Mobley et al., 1994; Fields and Blum, 1997). To test whether or not there are consistent statistically significant gender differences in job satisfaction levels and its determinants across countries, descriptive mean scores and OLS regression results where compared across countries for the 2015 wave of the ISSP survey (full results by country are available by request). Table 2 shows little difference in mean job satisfaction scores between men and woman for the entire global sample (slightly in favor of men), with little difference in each of the intrinsic job characteristics. However, there were significant differences in pay, promotional opportunities, physical effort (significantly lower mean scores for women), work weekends, and flexibility to deal with family members (significantly higher mean scores for women), as well as in education level (women in the sample were significantly more education, on average, than men) and work hours (men worked consistently more hours, on average, than their female counterparts).

Furthermore, additional detailed OLS regression models were run (tables of results not provided here due to space restrictions; available upon request) for each specific country in the 2015 wave of the ISSP work orientations ISSP. Gender is only statistically significant 1 of the 37 countries (full descriptive statistics and regression results by country are available upon request). Finally, Table 4 shows OLS regression results for men and women separately. There is virtually no difference in extrinsic work characteristics between men and women, with only slight difference in intrinsic work characteristics; namely "Help Others" is significant for women but not for men. However, while there was virtually no difference in many of the work relation and work-life balance variables, "Contact with Others," "Harassed at Work," "Work Weekends," and "Schedule Flexibility" are all statistically significant for men and not for women in the global sample.

Therefore, $\mathrm{H} 1$ is supported by these results, namely that there are not consistent statistically significant gender differences in job satisfaction levels across countries. Furthermore, H2a is not supported by these results, namely, there is no statistical difference between the saliency of extrinsic job factors on the just satisfaction of men and women (with little difference in standardized beta coefficient strength and statistical significance between men and women). H2b is partially supported, in that "Help Others" is statistically significant for women and not for men (all other intrinsic variables are roughly the same for both genders). Interestingly, contrary to what was expected from the literature, $\mathrm{H} 2 \mathrm{c}$ and $\mathrm{H} 2 \mathrm{~d}$ are not supported by the data, and in fact the opposite is true; work relations and work-life balance variables are more salient for male workers than female works across the globe (based on the differences in standardized beta coefficient strength and statistical significance between men and women).

\section{DISCUSSION}

Questions about how gender impacts people in the workplace still remain highly relevant today. For one thing, gender and gender roles are much more fluid today than in the past. Additionally, considering gender as a social construct, it is reasonable to think that shifts in the perceptions of women and women's roles might take place, and that those perceptions might differ in different cultural contexts.

As was mentioned previously, the paradox of the satisfied female worker has held that women are more satisfied with their jobs than men are, despite making less money (Clark, 1997; Donahue \& Heywood, 2004). However, this study found that as of the 2015 wave of the ISSP, this paradox no longer exists. It is possible that it never existed in the first place, since not all previous studies detected this difference. But it is also quite possible that this reflects the societal changes where women are much more integrated into the workplace, both functionally and psychologically. It is also interesting that with one exception, that the level of satisfaction among both men and women was the same across multiple 
countries. This adds support to the idea that the influence of gender has decreased and that broad socioeconomic forces may be at work in job satisfaction.

The fact that women and men are similar in their satisfaction levels at work, shows that gender differences are becoming less relevant. Where previously, a woman might be expected to remain satisfied even when things were not ideal, while a man might become dissatisfied is not a likely scenario today. The ability (whether conscious or not) to be less concerned about a woman's satisfaction than a man's no longer exists.

The other aspect of the paradox is that women still are subject to a pay gap when compared to men. However, since salary by itself only exhibits an effect on satisfaction prior to reaching a living wage, it is not that perplexing. Though women are still not treated fairly and may experience issues regarding their perceptions of justice, these perceptions do not appear to impact their level of job satisfaction. So, the paradox may not have been as real as it appeared since salary's effect on satisfaction is limited for people earning a reasonable wage.

Another important finding in this study was that men and women seem equally affected by extrinsic rewards. Again, this could be explained by the fact that the roles of men and women are less differentiated than in the past. In decades past, there was the assumption that the man was the breadwinner and the woman took a job to supplement the family's income. In that scenario, women might not be as concerned that their job provided stability, opportunities for growth, or even that a job was stressful as they could always simply leave if things were bad. However, today working is seen as a joint responsibility and it would make sense that if men and women have a similar view of their roles as income producers, it would make sense that satisfaction would be driven by the same forces.

Interestingly, in terms of intrinsic factors, men and women were also not that different from men with the exception of the help others factor. While it is interesting that men and women are different in terms of how their ability to help others impacts their satisfaction, what is even more curious is that the ability to help others is significant for women, but not for men. This means that although men and women both derive satisfaction from doing work that is interesting, provides them with autonomy, and is useful to society as a whole, men are not as impacted by their work being perceived as directly helpful to others. This does fit the stereotype of men being more instrumental about work then women.

For the work relations variables, it turns out that for men, having personal contact with others was significant while for women it was not. This suggests that perhaps men have fewer personal contacts outside of work, while women may have a better network outside. In a surprising result the link between harassed at work and satisfaction was significant for men, but not for women. In this age of the "me too" movement one would expect that harassment for women would be an important factor in how they feel about work. It is possible that women across the globe, women are not harassed as much as we believe them to be in the United States, or it is also possible that many women have compartmentalized harassment or suppressed it, or simply come to expect that it is unavoidable. Whatever the cause, this is an area where further research would be useful.

The final area we examined included the work-life variables. Again, we found that certain variables were significant for men, but not for women. Specifically, working weekends and schedule flexibility. This would once again seem like an area where women's satisfaction would be more dependent on having the flexibility to adjust their schedule on the fly or not having to work on weekends, but men's satisfaction was more affected by this than women's was. This could be the result of the fact we did find that the number of hours worked in a week were higher for men. It is possible that with the higher level of work hours that men need more flexibility to deal with issues that come up, since they just have less free time, and that extra hours on top of an already full schedule are more burdensome than if one was working fewer hours.

\section{CONCLUSION}

As societies change and the roles of men and women undergo shifts from the previous traditional expectations to a more undifferentiated set, it is likely that men and women will experience similar shifts 
in terms of their job satisfaction and the factors that influence it. This study found that overall, men and women now have similar levels of general job satisfaction across a large number of countries. However, there are still differences in terms of which factors are affecting that satisfaction, suggesting that men and women are still not completely identical in terms of what they want out of the experience of work. While we can expect that for variables that are influenced by job satisfaction such as turnover, we can expect similar behavior for men and women, we can't yet treat them exactly the same. This may mean that managers need to be aware of what things tend to be related to satisfaction for men and which are related for women. However, it is not unreasonable to think that over time, these differences may become less and less relevant.

\section{ENDNOTES}

1. Here we use one of four waves of cross-sectional data and therefore we cannot specifically test the direction of causality among the variables examined as easily as we might with panel longitudinal data. However, we provide a conceptual framework that hypothesizes the path of causality. Additionally, ISSP Researchers collected the data via self-administered questionnaires, personal interviews, and mail-back questionnaires, depending on the country. For a full summary and description of this research, see https://www.gesis.org/issp/modules/issp-modules-by-topic/work-orientations/2015/.

2. ISSP Researchers collected the data via self-administered questionnaires, personal interviews, and mailback questionnaires, depending on the country. For a full summary and description of this research, see the International Social Survey Program methodology description here: http://w.issp.org/aboutissp/methodology/.

3. Australia, Austria, Belgium, Chile, China, Taiwan, Croatia, Czech Republic, Denmark, Estonia, Finland, France, Georgia, Germany, Hungary, Iceland, India, Israel, Japan, Latvia, Lithuania, Mexico, New Zealand, Norway, Philippines, Poland, Russia, Slovak Republic, Slovenia, South Africa, Spain, Suriname, Sweden, Switzerland, United Kingdom, United States, Venezuela

4. Each variable is a single-item indicator.

5. Response categories for this variable include: (1) Completely Dissatisfied, (2) Very Dissatisfied, (3) Fairly Dissatisfied, (4) Neither Satisfied nor Dissatisfied, (5) Fairly Satisfied, (6) Very Satisfied, (7) Completely Satisfied.

6. Response categories for these variables include: (1) Strongly Disagree, (2) Disagree, (3) Neither Agree nor Disagree, (4) Agree, and (5) Strongly Agree.

7. Response categories for these variables include: (1) Strongly Disagree, (2) Disagree, (3) Neither Agree nor Disagree, (4) Agree, and (5) Strongly Agree.

8. Response categories for this variable include: (1) Always, (2) Often, (3) Sometimes, (4) Hardly Ever, (5) Never.

9. Response categories for this variable include: (1) Always, (2) Often, (3) Sometimes, (4) Hardly Ever, (5) Never.

10. Response categories for these variables include: (1) Very Bad, (2) Bad, (3) Neither good nor bad, (4) Good, and (5) Very Good.

11. Response categories for these variables include: (1) Very Bad, (2) Bad, (3) Neither good nor bad, (4) Good, and (5) Very Good.

12. Response categories for these variables include: (1) Strongly Disagree, (2) Disagree, (3) Neither Agree nor Disagree, (4) Agree, and (5) Strongly Agree.

13. Response categories for these variables include: (1) Yes, (2) No.

14. Response categories for these variables include: (1) Yes, (2) No.

15. Response categories for this variable include: (1) Always, (2) Often, (3) Sometimes, (4) Hardly Ever, (5) Never.

16. Response categories for this variable include: (1) Always, (2) Often, (3) Sometimes, (4) Hardly Ever, (5) Never.

17. Response categories for this variable include: (1) Starting and finishing times are decided by my employer and I cannot change them on my own,

18. Response categories for this variable include: (1) Not difficult at all, (2) Not too difficult, (3) Somewhat difficult, and (4) Very difficult. 
19. Response categories for this variable include: (1) Always, (2) Often, (3) Sometimes, (4) Hardly Ever, (5) Never.

20. Categories for this variable include: (1) Male, (2) Female.

21. Continuous variable.

22. Continuous variable.

23. Response categories for this variable include: (1) married, (2) civil partnership, (3) separated from spouse/civil partner(s), (4) divorced from spouse/ legally separated, (5) widowed/ civil partner died, (6) never married/ never in a civil partner

24. Continuous variable.

25. Continuous variable.

26. Categories for this variable include: (1) Managers, (2) Professionals, (3) Technicians and Associate Professionals, (4) Clerical Support Workers, (5) Services and Sales Workers, (6) Skilled Agricultural, Forestry and Fishery Workers, (7) Craft and Related Trades Workers, (8) Plant and Machine Operators and Assemblers, (9) Elementary Occupations, and (10) Armed Forces Occupations

27. Categories for supervising others: (1) Yes, (2) No.

28. Categories for this variable include: (1) Employee, (2) self-employed without employees, (3) self-employed with employees, and (4) working for own family's business.

29. Categories for type of organization: (1) Public, (2) Private

30. Due to the ordinal nature of the dependent variable, it is most appropriate to use an ordered probit regression to look at the effect of different job characteristics on one's overall job satisfaction. However, many researchers have argued that using OLS regression is appropriate when looking at satisfaction variables on a Likert scale, where most respondents understand that the difference between responses of 1 and 2 is the same as the difference between responses of 2 and 3, and so on. Additionally, using OLS regression results allows us to report an $\mathrm{r}$-squared and adjusted r-squared value for the model and compare coefficients across models, which comparison is not appropriate in a probit model. Therefore, all regression results reported herein are OLS regression result. It is important to note that when the same OLS models where run in an ordered probit regression, the same significant results appeared for each of the independent and control variables across countries and waves (full ordered probit model results, are available upon request). 


\section{REFERENCES}

Appelbaum, S., \& Kamal, R. (2000). An analysis of the utilization and effectiveness of nonfinancial incentives in small business. Journal of Management Development, 19(9), 733-763.

Bashaw, D. (1999). Gender earnings and job satisfaction: The case of US physicians. Ph.D. Dissertation, UMI Number 9916558, University of Wisconsin, Milwaukee.

Başlevent, C., \& Kirmanoğlu, H. (2014). The impact of deviations from desired hours of work on the life satisfaction of employees. Social Indicators Research, 118(1), 33-43.

Bassett, G. (1994). The case against job satisfaction. Business Horizons, 37(3), 61-68.

Brief, A. P. (1998). Attitudes in and around organizations. Thousand Oaks, CA: Sage.

Bernstein, D. A., \& Nash, P. W. (2008). Essentials of psychology (4th ed.). Boston: Cengage Learning. Retrieved from http://books.google.com/books?id=4Do-bFrt9tUC

Bender, K. A., Donohue, S. A., \& Heywood, J. S. (2005). Job satisfaction and gender segregation. Oxford Economic Papers, 57(3), 479-496.

Blau, G. (1994). Developing and testing a taxonomy of lateness behavior. Journal of Applied Psychology, 79(6), 959-70.

Brown, S. P., \& Lam, S. K. (2008). A meta-analysis of relationships linking employee satisfaction to customer responses. Journal of Retailing, 84(3), 243-255.

Bokemeier, J. L. \& William, B. L. (1987). Job values, rewards, and work conditions as factors in job satisfaction among men and women. The Sociological Quarterly, 28(2), 189-204.

Carleton, C. J., \& Clain, S. H. (2012). Women, men, and job satisfaction. Eastern Economic Journal, 38(3), 331-355.

Clerkin, C. (2017). What women want-and why you want women -in the workplace. Center for Creative Leadership. Retrieved from https://www.ccl.org/wpcontent/uploads/2017/07/WhatWomenWant.FINAL_.pdf

Clark, A., Oswald, A., \& Warr, P. (1996). Is job satisfaction U-shaped in age? Journal of Occupational and Organizational Psychology, 69(1), 57-81.

Clark, A. (1997). Job satisfaction and gender: Why are women so happy at work? Labour Economics, $4(4), 341-372$.

Dhawan, S. (2000). Work climate and gender: Why are women scientists so satisfied at work? Journal of Scientific and Industrial Research, 59(2), 121-131.

Donohue, S., \& Heywood, J. (2004). Job satisfaction, comparison income and gender: Evidence from the NLSY. International Journal of Manpower, 25(2), 211-234.

Dyke, L. S., \& Murphy, S. A. (2006). How we define success: A qualitative study of what matters most to women and men. Sex Roles, 55(5-6), 357-371.

Employee Retention Headquarters. (n. d.). Attracting, retaining and motivating employees: The realities and options. Retrieved from http://www.employee-retention-hq.com/

Ehrenberg, R. G. (2003). Studying ourselves: the academic labor market. Journal of Labor Economics, 21(2), 267-287.

Fields, D. L., \& Blum, T. C. (1997). Employee satisfaction in work groups with different gender composition. Journal of Organizational Behavior, 18(2), 181-196.

Fricke, M. A. M., \& Beehr, T. A. (1992). A longitudinal investigation of interest congruence and gender concentration as predictors of job satisfaction. Personnel Psychology, 45(1), 99-117.

Garrido, M. J., Perez, P., \& Anton, C. (2005). Determinants of sales manager job satisfaction: An analysis of Spanish industrial firms. International Journal of Human Resource Management, 16(1), 19341954.

Grant, A. M., Fried, Y., \& Juillerat, T. (2010). Work matters: Job design in classic and contemporary perspectives. In S. Zedeck (Ed.), APA handbook of industrial and organizational psychology 1 (417-453). Washington, DC: American Psychological Association. 
Grissom, J. A., Nicholson-Crotty, J. \& Keiser, L. (2012). Does my boss' gender matter? Explaining job satisfaction and employee turnover in the public sector. Journal of Public Administration Research and Theory, 22(4), 649-673.

Harris, J. I., Moritzen, S. K., Robitschek, C., Imhoff, A., \& Lynch, J. L. A. (2001). The comparative contribution of congruence and social support on career outcome. The Career Development Quarterly, 49(4), 314-323.

Hodson, R. (2002). Demography or respect? Work group demography versus organizational dynamics as determinants of meaning and satisfaction at work. The British Journal of Sociology, 53(2), 291 317.

Hull, K. (1999). The paradox of the contented female lawyer. Law and Society Review, 33(3), 687-702.

Kerber, K. W., \& Campbell, J. P. (1987). Job satisfaction: Identifying the important parts among computer sales and service personnel. Journal of Business and Psychology, 1(4), 337-352.

Konrad, A., Corrigall, E., Lieb, P., \& Ritchie, J. (2000). Sex differences in job attribute preferences among managers and business students. Group and Organization Management, 25(2), 108-131.

Koys, D. J. (2001). The effects of employee satisfaction, organizational citizenship behavior, and turnover on organizational effectiveness: A unit-level, longitudinal study. Personnel Psychology, 54(1), 101-114.

Kristensen, N., \& Johansson, E. (2008). New evidence on cross-country differences in job satisfaction using anchoring vignettes. Labour Economics, 15(1), 96-117.

Kessler, S. R., Spector, P. E., \& Gavin, M. B. (2012). A critical look at ourselves: Do male and female professors respond to the same environment characteristics? Research in Higher Education, 55(4), 350-361.

Lee, T. (1998). Job satisfaction leads to turnover. Journal of Business and Psychology, 2(1), 263-271.

Locke, E. A. (1976). The nature and causes of job satisfaction. In M. D. Dunnette (Ed.), Handbook of industrial and organizational psychology (pp. 1297-1349). Chicago, IL: Rand McNally.

Losocco, K., \& Bose, C. (1998). Gender and job satisfaction in urban China: The early post-Mao period. Social Science Quarterly, 79(1), 91-109.

Lusch, R. F., \& Serpkenci, R. R. (1990). Personal differences, job tension, job outcomes, and store. Journal of Marketing, 54(1), 85-101

Magee, W. (2014). Effects of gender and age on pride in work, and job satisfaction. Journal of Happiness Studies, 16(5), 1091-1115. doi:10.1007/s10902-014-9548-x

McDuff, E. (2001). The gender paradox in work satisfaction and the protestant clergy. Sociology of Religion, 62(1), 1-21.

Metle, M. (2001). Education, job satisfaction and gender in Kuwait. International Journal of Human Resource Management, 12(2), 311-332.

Mobley, G. M., Jaret, C., Marsh, K., \& Lim, Y. Y. (1994). Mentoring, job satisfaction, gender, and the legal profession. Sex Roles, 31(1/2), 79-98.

Mulinge, M., \& Mueller, C. (1998). Employee job satisfaction in developing countries: The case of Kenya. World Development, 26(12), 2181-2199.

Ng, T. W. H., \& Feldman, D. C. (2010). The relationship of age with job attitudes: a meta-analysis. Personnel Psychology, 63(3), 677-718

Ngo, H. Y., Foley, S., Ji, M. S., \& Loi, R. (2014). Work satisfaction of Chinese employees: A social exchange and gender-based view. Social Indicators Research, 116(2), 457-473.

Oshagbemi, T. \& Hickson, C. (2003). Some aspects of overall job satisfaction: A binomial logit model. Journal of Managerial Psychology, 18(4), 357-367.

Ostroff, C. (1992). The relationship between satisfaction, atti tudes, and performance: An organizational level analysis. Journal of Applied Psychology, 77(6), 963-974.

Robst, J., VanGilder, J., \& Polachek, S. (2003). Perceptions of female faculty treatment in higher education: which institutions treat women more fairly? Economics of Education Review, 22(1), 59-67. 
Rogers. J. D., Clow, K. E., \& Kash, T. J. (1994). Increasing job satisfaction of service personnel. Journal of Service Management, 8(1), 14-26.

Ryan, A. M., Schmit, M. J., \& Johnson, R. (1996). Attitudes and effectiveness: Examining relations at an organizational level. Personnel Psychology, 49(4), 853-882.

Sloane, P. J., \& Williams, H. (2000). Job satisfaction, comparison earnings and gender. Labour, 14(3), 473-502.

Smart, J. C., \& Ethington, C. A. (1987). Occupational sex segregation and job satisfaction of Women. Research in Higher Education, 26(2), 202-211.

Sousa-Pouza A., \& Sousa-Pouza A. A. (2000). Well-being at work: A cross-national analysis of the levels and determinants of job satisfaction, Journal of Socio-Economics, 29(6), 517-538.

Syptak, J.M., Marsland, D.W., \& Ulmer, D. (1999). Job satisfaction: Putting theory into practice. Family Practice Management, 6(9). 26-30. Retrieved from http://www.aafp.org/fpm/991000fm/26.html

Tait, M., Padgett, M.Y., \& Baldwin, T.T. (1989). Job and life satisfaction: A reexamination of the strength of the relationship and gender effects as a function of the date of the study. Journal of Applied Psychology, 74(3), 502-507.

Tietjen, M. A., \& Myers, R. M. (1998). Motivation and job satisfaction. Management Decision, 36(4), 226-231.

Vroom, V. H. (1964). Work and motivation. New York, NY: Wiley.

Vroom, V. H. (1995). Work and motivation (2nd ed.). New York, NY: Wiley.

Westover, J. H. (2009). A cross-national look at the changing nature of gender differences in perceived job satisfaction. International Journal of Global Business and Economics, 2(1), 62-67.

Wilks, D. C., \& Neto, F. (2013). Workplace well-being, gender and age: Examining the 'double jeopardy' effect. Social Indicators Research, 114(3), 875-890.

Yap, M., \& Konrad, A. M. (2009). Gender and racial differentials in promotions: Is there a sticky floor, a mid-level bottleneck, or a glass ceiling? Relations Industrialles, 64(4), 593-619.

Zoghi, C. (2003). Why have public university professors done so badly? Economics of Education Review, 22(1), 45-57.

40 Journal of Business Diversity Vol. 19(3) 2019 